\title{
Review of accessibility and usability guidelines for website design for the elderly people
}

Diego Fernando Aguirre / diego.aguirre@correounivalle.edu.co

Iván Abadía, MSc. (c) / ivan.abadia@correounivalle.edu.co

Universidad del Valle, Cali-Colombia

ABSTRACT By 2050, the growth of the elderly population in Colombia is estimated at 10\% and thus a greater demand for special services (such as health services) for the elderly. This justifies the exploration of digital health content as an important source of information for this population. The accessibility and usability guidelines for website design - e.g., TAW and WACG- do not have specific guidelines to mitigate the motor, cognitive or visual disabilities characteristic of aging, which become a barrier for this group to consult necessary information for administrative processes that involve health. This review of accessibility and usability guidelines is presented, facilitating the consumption of specific contents and generating better interactions with such systems, which will lead to the construction of guidelines based on existing recommendations that allow the development of aspects related to interaction, legibility and usability in digital content for the elderly.

KEYWORDS Usability; human-computer interaction.

Revisión de lineamientos de accesibilidad y usabilidad para el diseño de sitios web para personas de la tercera edad

RESUMEN Para el 2050 se estima en 10\% el crecimiento de la población mayor en Colombia y con ello una mayor demanda de servicios especiales (como los de salud) para la tercera edad. Esto justifica que se exploren contenidos digitales de salud como una fuente importante de información para dicha población. Los lineamientos de accesibilidad y usabilidad para el diseño de sitios web - e.g., TAW y WACG- no poseen lineamientos específicos para mitigar las discapacidades motrices, cognitivas o visuales, propias del envejecimiento, que se convierten en una barrera para que este grupo consulte información necesaria para los procesos administrativos que involucran su salud. Se presenta esta revisión de lineamientos de accesibilidad y usabilidad, que facilitan el consumo de contenidos específicos y generan mejores interacciones con dichos sistemas, lo que propiciará la construcción de lineamientos basados en recomendaciones ya existentes que permitan desarrollar aspectos relacionados con la interacción, legibilidad y usabilidad en contenidos digitales para personas de la tercera edad.

PALABRAS CLAVE Usabilidad; interacción humano-computador.
Revisão das diretrizes de acessibilidade e usabilidade para a criação de sites para 0 população idosa

RESUMO O crescimento da população idosa na Colômbia em 2050 é estimado em 10\% e, com isto, uma maior demanda de serviços especiais (como serviços de saúde) para idosos. Isto justifica a exploração de conteúdos digitais de saúde como uma importante fonte de informação para essa população. As diretrizes de acessibilidade e usabilidade para o criação de websites - por exemplo, TAW e WAGG - não possuem diretrizes específicas para mitigar as deficiências motoras, cognitivas ou visuais características do envelhecimento, que se tornam uma barreira para que este grupo consulte as informações necessárias sobre os processos administrativos que envolvem sua saúde. É apresentada esta revisão das diretrizes de acessibilidade e usabilidade, facilitando o consumo de conteúdos específicos e gerando melhores interações com esses sistemas, o que levará à construção de diretrizes baseadas em recomendações existentes que permitam o desenvolvimento de aspectos relacionados à interação, legibilidade e usabilidade em conteúdos digitais para a população idosa.

PALAVRAS-CHAVE Usabilidade; interação humano-computador. 


\section{Introduction}

Within the objectives of the ICT plan 2008-2019 of the Ministry of Telecommunications of Colombia, it is intended that "all Colombians be connected and informed by making efficient use of ICT to improve social inclusion and competitiveness..." (Ministerio de Salud y Protección Social, 2016). In Colombia, according to the Health, Welfare and Aging survey - SABE 2015 (Ministry of Health and Social Protection, 2015), 48.9\% of the elderly people over 65 years of age are affiliated to the contributory health regime, $46.8 \%$ to the subsidized regime, $0.4 \%$ to the exception regime, $1.6 \%$ to the special regime and only $2.2 \%$ do not belong to any regime; this shows that only about half of that population can pay for a health system on their own. On the other hand, the higher strata have a complementary health plan, of which $95.2 \%$ are senior citizens of strata 5 and 6 . This shows that only a small fraction of the elderly population can access to a quality health service. Such deficiency of homogenous coverage of the Colombian health system opens the possibility of considering Information and Communication Technologies [ICT] as an alternative that balances the provision of these services, so the way in which the digital contents about health are present to this population, becomes in a relevant issue that the Service Providers Entities [EPS] of the sector should prioritize in their health delivery strategy.

\section{Telemedicine (e-Health) in Colom- bia}

Colombia presents a geographical dispersion that generates variations in the degree of access of people to public services (e.g. health service), affecting institutional management (Ministry of Health and Social Protection, 2016). The coverage levels of the health system are concentrated in the main county towns, so the access of rural population to these services is difficult (Aparicio \& Castang, 2006). These county towns contain the largest population of the country and present a constant increase of displaced population (Aparicio \& Castang, 2006), which implies an insufficiency in the optimal coverage of basic services, among them health.

Advances in ICT are understood as " ...the set of resources, tools, equipment, software, applications, networks and media, which allow the compilation, processing, storage, transmission of information such as voice, data, text, video and images" (Law 1341 of 2009) that allow to break the barriers and shorten the distances. These technological developments affect the social customs and the form of interaction between the individuals, and lead to the increase of

\section{Introducción}

Dentro de los objetivos del plan TIC 2008-2019 del Ministerio de Telecomunicaciones de Colombia se pretende que "todos los colombianos estén conectados e informados haciendo uso eficiente de las TIC para mejorar la inclusión social y la competitividad..." (Ministerio de Salud y Protección Social, 2016). En Colombia, según la encuesta de Salud, Bienestar y Envejecimiento - SABE 2015 (Ministerio de Salud y Protección Social, 2015), el 48,9\% de las personas de la tercera edad mayores de 65 años están afiliadas al régimen contributivo de la salud, el 46,8\% al régimen subsidiado, el $0,4 \%$ al régimen de excepción, el $1,6 \%$ al régimen especial y solo el 2,2\% no pertenece a ningún régimen; esto muestra que únicamente cerca de la mitad de esa población puede pagarse un sistema de salud por sus propios medios. Por otro lado, los estratos más altos poseen un plan complementario de salud, y de estos el $95.2 \%$ son personas adultas mayores de estratos 5 y 6 . Ello evidencia que tan solo una pequeña fracción de la población de adultos mayores puede acceder a un servicio de salud de calidad. Tal deficiencia de cobertura homogénea del sistema de salud colombiano abre la posibilidad de considerar a las Tecnologías de la Información y las Comunicaciones [TIC] como una alternativa que balancee la prestación de estos servicios, por lo que la manera cómo los contenidos digitales sobre salud se presenten a ésta población, se convierte en un tema relevante que las Entidades Prestadoras de Servicios [EPS] del sector deberían priorizar en su estrategia de prestación de salud.

\section{Telemedicina (e-Health) en Colombia}

Colombia presenta una dispersión geográfica que genera variaciones en el grado de acceso de las personas a los servicios públicos (entre los que se cuenta el de salud), afectando también la gestión institucional (Ministerio de Salud y Protección Social, 2016). Los niveles de cobertura del sistema de salud se encuentran concentrados en las principales cabeceras municipales, por lo que el acceso de los habitantes de zonas rurales a dichos servicios es difícil (Aparicio \& Castang, 2006). Estas cabeceras municipales contienen la mayor cantidad de población del país y presentan un aumento constante de población desplazada (Aparicio \& Castang, 2006) lo que conlleva una insuficiencia en la cobertura óptima de servicios básicos, entre ellos el de salud.

Los avances en las TIC son entendidas como "...el conjunto de recursos, herramientas, equipos, programas informáticos, aplicaciones, redes y medios, que permiten la compilación, procesamiento, almacenamiento, transmisión de información como voz, datos, texto, video e imágenes" (Ley 1341 de 2009) que permiten romper las barreras y acortar las distancias. Estos desarrollos tecnológicos afectan las costumbres sociales y la forma de interactuar entre los individuos, y conllevan al aumento de oportunidades para grupos poblacionales apartados y dispersos por el territorio nacional (Ministerio de Salud y Protección Social, 2014). 
Según el Sistema General de Seguridad Social [SGSS] en 2014 se habilitaron 2.184 servicios de telemedicina en 685 sedes de servicios de salud en todo el territorio nacional, principalmente en Antioquia y Bogotá -las áreas con más servicios habilitados-y en los departamentos del Valle del Cauca y Bolívar (Ministerio de Salud y Protección Social, 2016).

Según el reporte de ése mismo año, en el Valle del Cauca se habilitaron 95 sedes que corresponden al 13,87\% de las sedes que prestan servicios de telemedicina, y 216 servicios, que corresponden al 9,89\% del total de servicios en telemedicina del país (Ministerio de Salud y Protección Social, 2016).

Los entes gubernamentales, como el SGSS en Colombia, tienen la responsabilidad de implementar las medidas y herramientas necesarias para que los servicios de salud tengan completa cobertura en todo el país y sean óptimos (Aparicio \& Castang, 2006). Uno de los medios para la prestación de telemedicina implementados por los centros de salud a nivel nacional son sus portales web institucionales. Aparicio y Castang (2006) encuentran que los portales web de salud en Colombia se limitan únicamente a brindar información sobre servicios proporcionados por las EPS, pero no aprovechan todos los beneficios que la atención en línea puede ofrecer: atención a pacientes a distancia, prevención y atención y educación en línea, lo que lleva a pensar que la concepción que se tiene acerca de la implementación de sitios web está sesgada, limitada o mediatizada, ya que se usa con fines más internos que externos.

\section{Legislación sobre accesibilidad y usa- bilidad web en Colombia}

Según Varela et al., (2012) en Colombia solo existen leyes sobre igualdad de oportunidades y derecho de acceso a la información, pero no leyes específicas sobre accesibilidad web. Por otro lado, mediante el Decreto 2693 de 2014, del Ministro de Tecnologías de la Información y las Comunicaciones [MinTIC] (Carvajal \& Saab, 2010), el Gobierno concluye los lineamientos generales para el funcionamiento del programa de Gobierno en Línea, y establece los plazos y el seguimiento para que los servicios prestados mediante el mismo sean cumplidos. En la misma norma, el artículo siete dicta los aspectos generales a tener en cuenta en la prestación de servicios y lo que refiere a accesibilidad a ellos por parte de los usuarios. Por otra parte, mediante la Ley 1680 de 2013, el MinTIC establece los requisitos de accesibilidad que se deben tener en cuenta para personas en situación de ceguera o con baja visión.

En cuanto a estándares de accesibilidad, la norma Icontec-5854/2011 se basa en los lineamientos de accesibilidad propuestos por la WCAG y la iniciatiava WAI, que se convierte en el validador de accesibilidad y usabilidad automático colombiano, que se retomará más adelante. opportunities for population groups separated and dispersed throughout the national territory (Ministry of Health and Social Protection, 2014).

According to the General Social Security System [SGSS] in 2014, 2.184 telemedicine services were enabled in 685 health service seats throughout the national territory, mainly in Antioquia and Bogotá - the areas with the most services enabled- and in the departments of Valle del Cauca and Bolivar (Ministry of Health and Social Protection, 2016).

According to the report of the same year, in the Valle del Cauca, 95 seats were enabled, corresponding to $13.87 \%$ of the seats that provide telemedicine services, and 216 services, corresponding to $9.89 \%$ of the total telemedicine services of the country (Ministry of Health and Social Protection, 2016).

Government entities, such as the SGSS in Colombia, have the responsibility of implementing the necessary measures and tools to ensure that health services are fully covered throughout the country and are optimal (Aparicio \& Castang, 2006). One of the means for the provision of telemedicine implemented by health centers at the national level are its institutional web portals. Aparicio \& Castang (2006) find that health web portals in Colombia are limited to giving information on services provided by EPS, but do not take advantage of all the benefits that online care can offer: remote patient care, prevention and attention and online education, which leads to think that the conception that has about the implementation of websites is biased, limited or mediated, as it is used for more internal than external purposes.

\section{Legislation on web accessibility and usability in Colombia}

According to Varela et al., (2012) in Colombia there are only laws about equal opportunities and right of access to information, but not specific laws about web accessibility. On the other hand, through Decree 2693 of 2014, the Minister of Information Technologies and Communications [MinTIC] (Carvajal \& Saab, 2010), the Government concludes the general guidelines for the operation of the Online Government program, and establishes the deadlines and the monitoring so that the services provided by the same are fulfilled. In the same rule, article seven dictates the general aspects to be taken into account in the provision of services and what refers to accessibility to them by users. On the other hand, through Law 1680 of 2013, the MinTIC establishes the requirements of accessibility that must be taken into account for people in situation of blindness or with low vision. 
In terms of accessibility standards, the Icontec-5854/2011 standard is based on the accessibility guidelines proposed by the WCAG and the initiative WAI, which becomes the automatic accessibility and usability validator in Colombia, which will be taken up later.

\section{Health content on the Internet}

In Spain, Jiménez, García and Bermudez (2009) analyzed the health websites of 78 large hospitals and showed that, in general, their quality and usability is low. It was concluded that they should increase the interaction with society outside the establishments through quality webs and demonstrated that they are possibly accessible to present information to the professional individual and to hospital providers, but they do not prioritize contents for those who use their services (Calvo, 2014). The fact that the main health centers determine contents that prioritize information at an internal level of the establishment, frustrates the processes of information exchange between the audience (patients) and the issuer (EPS, private or public hospital), reduces the audience and turns passive the communicative process between both (Fenoll, 2011).

Internet browsers are fairly efficient at locating information regarding a specific topic. In the United States of America, Berland et al. (2001) reviewed the pertinence, precision, and level of specialization of health content in portals in English and Spanish, comparing them to each other. Their study revealed that half of Internet consumers report spending about half an hour looking for a single health issue and expose the search engine performance to be optimal and, therefore, a priority when it comes to searching for content on the Internet.

A study of the contents of the pages about Spanish-speaking arterial hypertension (Trabalón, 2012) shows that although information on the Internet is moderately acceptable, not all of it is directed to the general population, which could confuse the user. This study selects 23 websites and analyzes them through the "questionnaire to evaluate health web sites according to European criteria" developed by Jiménez, García, Martín and Bermudez (2011), which evaluates more general aspects when developing or analyzing the design and development of a website, such as accessibility, transparency and lack of interest; authorship; personal data protection; updating the information and responsibility of the services.

The elderly people use the Internet very little today $(22 \%$ of the total elderly population). However, the slightly younger population (59 to 68 years) is more adapted to the Internet and ICT, and uses technology to obtain information

\section{Contenidos sobre salud en Internet}

En España, Jiménez, García y Bermudez (2009) analizaron los sitios web de salud de 78 hospitales de gran tamaño y demostraron que, en general, su calidad y usabilidad es baja. Concluyeron que deberían aumentar la interacción con la sociedad fuera de los establecimientos mediante webs de calidad y demostraron que son posiblemente accesibles para presentar información al individuo profesional y para los proveedores del hospital, pero que no priorizan contenidos para quienes usan sus servicios (Calvo, 2014). El hecho de que los principales centros de salud determinen contenidos que prioricen la información a nivel interno del establecimiento frustra los procesos de intercambio de información entre la audiencia (pacientes) y el emisor (EPS, hospital privado o público), reduce la audiencia y vuelve pasivo el proceso comunicativo entre ambos (Fenoll, 2011).

Los buscadores de Internet son medianamente eficientes para localizar información respecto a un tema específico. En los Estados Unidos de América, Berland et al., (2001) revisaron la pertinencia, precisión y nivel de especialización de los contenidos sobre salud en portales en inglés y español, comparándolos entre sí. Su estudio reveló que la mitad de los consumidores de Internet reportan que pasan cerca de media hora buscando un solo tema sobre salud y expone la necesidad de que el funcionamiento de los motores de búsqueda sea óptimo y, por tanto, una prioridad a la hora de buscar contenidos en la Internet.

Un estudio sobre los contenidos de las páginas sobre hipertensión arterial de habla hispana (Trabalón, 2012) muestra que, aunque la información en Internet es medianamente aceptable, no toda está dirigida a la población general, lo que podría confundir al usuario. Este estudio escoge 23 sitios web y los analiza mediante el "cuestionario para evaluar sitios web sanitarios según criterios europeos" desarrollado por Jiménez, García, Martín y Bermudez (2011), el cual evalúa aspectos más generales al momento de desarrollar o analizar el diseño y desarrollo de un sitio web, tales como la accesibilidad, transparencia y ausencia de intereses; autoría; protección de datos personales; actualización de la información y responsabilidad de los servicios.

Las personas de la tercera edad usan poco el Internet en la actualidad $(22 \%$ del total de población de la tercera edad). Sin embargo, la población un poco más joven (59 a 68 años) está más adaptada a Internet y a las TIC, y usa la tecnología para obtener información acerca de aspectos de salud (Jiménez et al., 2009). Este fenómeno podría cambiar los estigmas sociales frente al uso del Internet por parte de la población de la tercera edad. Es común pensar en una disociación entre la tecnología y esta población, debido a que se atribuye la legitimidad de las discapacidades propias de la edad: cognitivas, motrices, visuales, auditivas, etc. Sin embargo, diferentes estudios (Aldana, García, \& Jacobo, 2012) han logrado demostrar que la estimulación 
constante de las diferentes capacidades de las personas de la tercera edad mediante las TIC -aunque no sean el único medio-, no solo permiten mantener el nivel cognitivo del individuo, sino también incrementarlas, inclusive hasta después de los 80 años.

El crecimiento demográfico constante y la baja natalidad han provocado un acelerado envejecimiento de la población mundial. Según la ONU, para 2050 la tercera edad representará un $21 \%$ de la población total, lo que se traduce en cerca de dos mil millones de personas (Allés, 2012). Esto trae consigo una enorme demanda de diferentes tipos de servicios y productos específicos para ésta población (Jiménez et al., 2009) Un estudio acerca del uso de Internet en los Estados Unidos muestra que lo utiliza el 22\% de las personas mayores de 65 años y alrededor de $45 \%$ de las personas un poco más jóvenes -entre 55 y 65 años(Jiménez et al., 2009), por lo que se podría suponer que un mayor uso de las TIC por parte de la tercera edad se traduciría en usos más amplios y demanda de más servicios y productos para ésta población, lo que abriría nuevos mercados para empresas de diversos sectores. Sin embargo, para poder satisfacer a plenitud las necesidades de ese grupo poblacional, las empresas deberán considerar sus características particulares, entre ellas las discapacidades propias de la edad.

\section{Diseño universal}

La igualdad es un derecho universal estipulado en la Declaración Universal de los Derechos Humanos, por tanto, todos los servicios deben estar al alcance de todos los ciudadanos, sin exclusión alguna (Allés, 2012). Esto sugeriría que las empresas deben adaptar su oferta de bienes y servicios, según las posibilidades de acceso de cada usuario de la tercera edad en su segmento del mercado. El producto, por tanto, deberá cumplir con ciertos criterios de accesibilidad: físicos, el producto en sí mismo; comunicativos, el diseño gráfico y las etiquetas; y el canal de distribución que permita llegar al usuario que lo ha solicitado (Allés, 2012). Esto también aplicaría para contenidos web, más aún hoy, cuando el ciberespacio se ha convertido en un lugar donde convergen diferentes necesidades.

Rafe y Monfaredzadeh (2012) establecen que además de las mejoras en la prestación de los servicios, el uso de Internet posibilita que los hospitales proporcionen más servicios cualificados, con menores gastos y en menor tiempo, e incluso les permite superar sus competidores.

\section{Accesibilidad}

Según Petrié y Edwards (2001), existen muchos factores que median el proceso de diseño de accesibilidad en los productos y servicios, y muchas definiciones respecto de lograr que un producto o sistema sea usable y accesible para dos personas con discapacidades distintas. Recomienda que, quienes diseñen accesibilidad y usabilidad, deben tener claro aspectos universales del usuario y microambientes, como los aspectos legales y las características de about health aspects (Jiménez et al., 2009). This phenomenon could change the social stigmas against the use of the Internet by the elderly population. It is common to think of dissociation between technology and this population, because the legitimacy of age-specific disabilities is attributed: cognitive, motor, visual, auditory, etc. However, different studies (Aldana, García, \& Jacobo, 2012) have demonstrated that the constant stimulation of the different capacities of the elderly people through ICT -although they are not the only means-, not only allow to maintain the cognitive level of the individual, but also to increase them, even after the 80 years.

Constant demographic growth and low birth rates have led to an accelerated aging of the world population. According to the UN, by 2050 the old age will represent $21 \%$ of the total population, which turns into about two billion people (Allés, 2012). This brings with it an enormous demand for different types of services and specific products to this population (Jiménez et al., 2009). A study about Internet use in the United States shows that it is used by $22 \%$ of people over 65 years and about $45 \%$ of the slightly younger people -between 55 and 65 years-(Jiménez et al., 2009), so it could be assumed that a greater use of ICT by the elderly people would result in wider uses and demand for more services and products for this population, which would open new markets for companies in different sectors. However, in order to fully satisfy the needs of this population group, companies should consider their particular characteristics, including age-specific disabilities.

\section{Universal Design}

Equality is a universal right stipulated in the Universal Declaration of Human Rights, therefore, all services must be available to all citizens, without any exclusion (Allés, 2012). This would suggest that companies must adapt their offer of goods and services, depending on the access possibilities of each senior citizen in their market segment. The product, therefore, must meet certain criteria of accessibility: physical, the product itself; communicative, graphic design and labels; and the distribution channel that allows reaching the user who requested it (Allés, 2012). This would also apply to web content, even more today, when cyberspace has become a place where different needs converge.

Rafe and Monfaredzadeh (2012) state that in addition to the improvements in the provision of services, the use of the Internet enables hospitals to provide more qualified services, with lower expenses and in less time, and even allows them to outperform their competitors. 


\section{Vl. Accessibility}

According to Petrié and Edwards (2001), there are many factors that mediate the process of designing accessibility in products and services, and many definitions regarding making a product or system usable and accessible to two people with different disabilities. It is recommended that, those who design accessibility and usability should have clear universal aspects of the user and microenvironments, such as legal aspects and the characteristics of disabilities, among others: that there are people with disability situations, the needs that these people have with their disabilities have a relationship with technology and finally, how they can include those needs in the final development of accessible technology.

On the other hand, web usability and accessibility not only benefits people with physical, psychic, motor or sensory disabilities, but also all users in general (Oleo \& Rodríguez, 2013).

According to Arch (2008), some of the benefits that the World Wide Web Consortium [W3G] considers are:

- benefits new or infrequent users, and improves access to users with slow connections or old technologies;

- improves the usability and accessibility of non-disabled people, disabled people and the elderly people;

- supports literacy levels through a clear, consistent and logical navigation style throughout the website;

- simplifies and reduces site development and maintenance time, which reduces server load; and

- facilitates interoperability by enabling a good level of interaction, giving access to the device through different devices and configurations, depending on the characteristics or preferences of users.

In order for health services offered via web to be efficient for the user, it is necessary to take into account the pertinence of the accessibility and usability standards that allow the elderly users an intuitive and comfortable interaction for the execution of any task within the portal. In addition, the dissemination of available web accessibility tools would facilitate and stimulate accessible web design and development (Oleo \& Rodríguez, 2013).

\section{Guidelines, institutions and tools for evaluating web accessibility and usability}

\section{A. Automatic validators}

The tools for evaluating automatic accessibility and usability are those that analyze the structure of HTML code las discapacidades, entre otras: que existen personas con situaciones de discapacidad, que las necesidades que tienen estas personas con su discapacidad tienen una relación con la tecnología y finalmente, de qué manera pueden incluir esas necesidades en el desarrollo final de tecnología accesible.

Por otro lado, la usabilidad y accesibilidad web no solo beneficia a personas con discapacidades físicas, psíquicas, motrices o sensoriales, sino a todos los usuarios en general (Oleo \& Rodríguez, 2013).

Según Arch (2008), algunos de los beneficios que el World Wide Web Consortium [W3C] considera son:

- beneficia a los usuarios nuevos o poco frecuentes, y mejora el acceso a los usuarios con conexiones lentas o tecnologías antiguas;

- mejora la usabilidad y el acceso de las personas no discapacitadas, de las personas discapacitadas y de las personas mayores;

- apoya los niveles de alfabetización a través de un estilo de navegación clara, coherente y lógica, a través de todo el sitio web;

- simplifica y reduce el desarrollo del sitio y el tiempo de mantenimiento, lo que reduce la carga del servidor; y

- facilita la interoperabilidad al permitir alcanzar un buen nivel de interacción, dando acceso al dispositivo mediante diferentes dispositivos y configuraciones, según las características o preferencias de los usuarios.

Para que los servicios de salud ofrecidos vía web sean eficientes para el usuario, es necesario tener en cuenta la pertinencia de los estándares de accesibilidad y usabilidad que permitan a los usuarios de la tercera edad una interacción intuitiva y cómoda para la ejecución de cualquier tarea dentro del portal. Además, la divulgación de las herramientas de accesibilidad web disponibles facilitarían y estimularían el diseño y desarrollo web accesible (Oleo \& Rodríguez, 2013).

VII. Lineamientos, instituciones y herramientas para evaluación de accesibilidad y usabilidad web

\section{A. Validadores automáticos}

Las herramientas de evaluación de accesibilidad y usabilidad automáticas son aquellas que analizan de manera mecánica la estructura del código HTML. Sin embargo, la evaluación automática puede dejar de lado aspectos que no puede comprobar por no pertenecer a la estructura propia del documento HTML (Oleo \& Rodríguez, 2013). Tal es el caso de las etiquetas <alt> que son estipuladas por el diseñador y que contienen descripciones específicas de contenidos como: imágenes, videos y textos, puntajes tipográficos, colores y formas apropiados al usuario final, entre otros. En la TABLA 1 se presenta los validadores automáticos de mayor uso. 
Table 1. Most widely used automatic validators / Validadores automáticos de mayor uso (Oleo \& Rodríguez, 2013)

\begin{tabular}{ll}
\hline Validador & Detalle \\
\hline TAW Online & A tool based on the guidelines established in the WCAG, used to verify and check compliance with \\
(TAW CTIC, & all items of accessibility and usability proposed by WCAG 2.0, which guarantee optimal usability and \\
& accessibility during and after the execution of a platform or website (Arch, 2008). It is one of the most \\
& used tools by the Spanish-speaking population (Oleo \& Rodríguez, 2013) and takes into account the A, \\
& AA and AAA guidelines, which will be reviewed later / Herramienta basada en las pautas establecidas en la \\
& WCAG, usada para verificary chequear el cumplimiento de todos los items de accesibilidad y usabilidad propuestos \\
& por la WCAG 2.0, que garanticen usabilidady accesibilidad óptima durante y después de la realización de una \\
& plataforma o sitio web (Arch, 2008). Es una de las herramientas más usadas por la población de habla hispana \\
& (Oleo ES Rodríguez, 2013) y tiene en cuenta las pautas A, AA y AAA, que se revisarán posteriormente.
\end{tabular}

AChecker (2011) Check the HTML code of web pages and their level of compliance with the standards stipulated by the WCAG / Comprueba el código HTML de las páginas web y su nivel de cumplimiento con los estándares estipulados por la WCAG.

Examinator Validator of HTML code that rates with a number between 1 and 10 the level of compliance (2015) with the guidelines of WCAG 2.0. / Validador de código HTML que califica con un número entre 1 y 10 el nivel de cumplimiento con los lineamientos de la WCAG 2.0.

ntc5854 (Edu Validator similar to the previous ones that results from the Colombian proposal of the Icontect stanLabs, 2015) dard 5854/2011 that establishes the criteria of accessibility and usability for the design of governmental portals / Validador similar a los anteriores que resulta de la propuesta colombiana de la norma Icontec 5854/2011, que establece los criterios de accesibilidad y usabilidad para el diseño de portales gubernamentales.

\section{B. Lineamientos para accesibilidad y usabilidad generales}

\section{W3C}

Los principales objetivos de este consorcio se fijan en el límite de la inclusión social y la búsqueda de la igualdad en el uso de las tecnologías. Estipulan que una plataforma web es accesible y usable cuando logra ser usada por todas las personas sin importar el hardware, el software, el lenguaje del usuario, la cultura, la ubicación y la habilidad física o mental de éste, lo cual llaman Iniciativa de Accesibilidad Web [Web Accesibility Iniciative, WAI] (Arch, 2008). Tales protocolos determinan aspectos en el área de movilidad (acceso de internet móvil), calidad de contenido, optimización para motores de búsqueda [Search Engine Optimization, SEO], buenas prácticas en desarrollo y estandarización web (Arch, 2008).

\section{Web Content Accessibility Guidelines [WCAG]}

La W3C, basada en los siete principios de diseño Universal, propone cuatro pautas en las que se categorizan los niveles de accesibilidad y usabilidad, los lineamientos de la iniciativa WCAG establecen los protocolos para diseño inclusivo: perceptible, operable, comprensible y robusto. Estas pautas contienen, a su vez, criterios de conformidad: A, pauta que atribuye mayor importancia en cuanto a accesibilidad final; AA, elimina importantes barreras de acceso a la web; y AAA, menor importancia, pero confiere buen nivel de accesibilidad (Oleo \& Rodríguez, 2013).

Las normas de accesibilidad web con mayor aceptación son las de la WCAG 1.0, publicadas en 1999 por la W3C mechanically. However, automatic evaluation can leave aside aspects that cannot be verified because they do not belong to the proper structure of the HTML document (Oleo \& Rodríguez, 2013). Such is the case of $<$ alt $>$ tags that are stipulated by the designer and contain specific descriptions of contents such as: images, videos and texts, typographic scoring, colors and shapes appropriate to the end user, among others. TABLE 1 presents the most widely used automatic validators.

\section{B. General guidelines for accessibility and usability}

\section{W3C}

The main objectives of this consortium are set at the limit of social inclusion and the search for equality in the use of technologies. They stipulate that a web platform is accessible and usable when it can be used by all people regardless of the hardware, software, user language, culture, location and physical or mental ability, which they call the Web Accessibility Initiative Web [WAI] (Arch, 2008). These protocols determine aspects in the area of mobility (mobile internet access), content quality, search engine optimization [SEO], good practices in web development and standardization (Arch, 2008).

\section{Web Content Accessibility Guidelines [WCAG]}

The W3C, based on the seven principles of Universal design, proposes four guidelines in which levels of accessibility 
and usability are categorized, the guidelines of the WCAG initiative establish the protocols for inclusive design: perceptible, feasible, comprehensible and robust. These guidelines contain, in turn, compliance criteria: A, a guideline that attributes greater importance to final accessibility; AA, eliminates important barriers to access the web; and AAA, minor importance, but it confers a good level of accessibility (Oleo \& Rodríguez, 2013).

The most widely accepted web accessibility standards are those of WCAG 1.0, published in 1999 by the W3C (updated in 2008), they adapt the contents to new technologies and improve the application and implementation of the guidelines and criteria of accessibility and usability proposed by the previous version (W3C, 2008; Oleo \& Rodríguez, 2013).

In terms of accessibility and usability issues, the WAI initiative of $\mathrm{W} 3 \mathrm{C}$, through the WCAG, establishes the guidelines for inclusive web design based on the seven principles of universal design (Connel et al., 1997).

- Equal use: the design must be easy to use and suitable for all people regardless of their skills and abilities, must provide the same ways of use for all users: identical when possible and equivalent when it is not.

- Flexibility of use: the design must be adapted to a wide range of individual preferences and abilities and allow the user to choose the mechanism of interaction or to adapt to the rhythm of use.

- Simple and intuitive design: the design should be easy to understand, regardless of experience, knowledge, skills or level of concentration of the user, establishes that unnecessary complexity should be eliminated and prioritize the organization of the information according to its importance.

- Perceptible information: design must communicate effectively the information required by the user, regardless of the sensory capabilities or environmental conditions.

- Error-tolerant design: design must minimize the risks and consequences of accidental or unintended actions.

- Use with little physical effort: the design must be used effectively and comfortably and with the minimum possible effort, avoiding or at least minimizing repetitive actions.

- Space and access for use: spaces and sizes must be appropriate for access, reach, manipulation and use by the user, regardless of size, position or mobility. (actualizadas en 2008), ellas adaptan los contenidos a las nuevas tecnologías y mejoran la aplicación e implementación de los lineamientos y criterios de accesibilidad y usabilidad propuestos por la versión anterior (W3C, 2008; Oleo \& Rodríguez, 2013).

En cuanto a temas de accesibilidad y usabilidad, la iniciativa WAI de la W3C, mediante la WCAG, establece los lineamientos para el diseño web inclusivo con base en los siete principios de diseño universal (Connel et al., 1997).

- Igualdad de uso: el diseño debe fácil de usar y adecuado para todas las personas independientemente de sus capacidades y habilidades, debe proporcionar las mismas maneras de uso para todos los usuarios: idénticas cuando sea posible y equivalentes cuando no lo sea.

- Flexibilidad de uso: el diseño debe adecuarse a un amplio rango de preferencias y habilidades individuales y permitir al usuario elegir el mecanismo de interacción o adaptarse al ritmo de uso.

- Diseño simple e intuitivo: el diseño debe ser fácil de entender, independientemente de la experiencia, conocimientos, habilidades o el nivel de concentración del usuario, establece que se debe eliminar la complejidad innecesaria y priorizar la organización de la información de acuerdo con su importancia.

- Información perceptible: el diseño debe comunicar de manera eficaz la información necesaria para el usuario, independientemente de sus capacidades sensoriales o de las condiciones ambientales.

- Diseño tolerante a errores: el diseño debe minimizar los riesgos y las consecuencias de acciones accidentales o no intencionadas.

- Uso con escaso esfuerzo físico: el diseño debe ser usado eficaz y confortablemente y con el mínimo esfuerzo posible, se deben evitar o al menos minimizar las acciones repetitivas.

- Espacio y acceso para el uso: los espacios y tamaños deben ser apropiados para el acceso, alcance, manipulación y uso por parte del usuario, independientemente de su tamaño, postura o movilidad.

Estos principios de accesibilidad, aplicados a los productos y servicios ofrecidos a la comunidad, evitan la discriminación de la población en situación de discapacidad y mejoran sus condiciones de uso y calidad de vida. Los principios de diseño universal buscan, sobre todo, apoyar el proceso de diseño de objetos y entornos, de manera que éstos resulten inclusivos, prescindiendo de adaptaciones drásticas para su uso en diferentes grupos de población (Rovira, 2003). Tanto los principios de diseño universal, como los estándares de usabilidad y accesibilidad propuestos por la W3C, buscan apoyar los procesos de diseño con el fin de ampliar sus alcances.

\section{Las heurísticas básicas de Nielsen}

Nielsen (1995) estableció diez lienamientos básicos para que la usabilidad de un sitio web esté bien diseñada. 
- Visibilidad del estado del sistema: el sistema debe estar informando todo el tiempo al usuario de los diferentes procesos que está ejecutando durante un determinado tiempo y de manera razonable.

- Relación entre el sistema y el mundo real: el sistema debe hablar en el lenguaje del usuario, no en el del sistema, usando frases, imágenes y conceptos que sigan las convenciones del mundo real.

- Control y libertad del usuario: los usuarios desearán corregir acciones no esperadas por el sistema que ellos mismos han generado, por lo que el sistema debe dar una salida de emergencia claramente marcada.

- Consistencia y estándares: el sitio debe manejar convenciones establecidas que faciliten el entendimiento de los contenidos a los usuarios.

- Prevención de errores: en cuanto sea posible, se debe prevenir todo error en el sistema y anticipar toda acción inapropiada del usuario.

- Reconocimiento antes que recuerdo: las opciones para llevar a cabo un proceso en el sistema deben estar a mano, el usuario no debería recordar procesos ni información.

- Estética y diseño minimalista: los dialogos no deben contener información irelevante o poco usada, pues entraría en conflicto con la información pertinente.

- Ayuda a los usuarios: los errores se deben solucionar mediante un instructivo correcto que informe de manera precisa al usario.

- Ayuda y documentación: aunque el sitio no necesite usar documentación extra para su uso, es necesario incluir ayuda textual y documentación adicional para usuarios no experimentados que requieran asistencia.

Las heuristicas de Nielsen (1995) han sido un referente mundial en el diseño y diagnósitco de errores en interfaces de usuario, ya que establecen las bases para su desarrollo. Son lineamientos que agilizan la identificación de errores en cada área de ejecución en todo tipo de interfaces, pero no tiene en cuenta el tipo de usuario que usa la interfaz (Becker, 2004), lo que claramente establece una necesidad de que los lineamientos incluyan a personas en situación de discapacidad. Pérez (2008) las usó para ejecutar una evaluación manual de tres sitios web dirigidos a personas de la tercera edad y el TAW CTIC (2011) para la evaluación automática de las interfaces de cada sitio.

\section{Recomendaciones de Shneiderman y Plaisant}

Se trata de ocho recomendaciones para el diseño de interacción humano-computadora. Estas recomendaciones son de gran utilidad cuando se van a diseñar interfaces que se encuentran basadas en los requerimientos específicos de los usuarios (Shneiderman \& Plaisant (2005).

- Consistencia: se deben usar iconos, colores, fuentes y demás elementos de diseño que sean familiares para el usuario, para no obligarles a aprender nuevos y que puedan usar algo de su acervo cognitivo ya aprehendido.
These principles of accessibility, applied to products and services offered to the community, avoid discrimination of the population in a situation of disability and improve their conditions of use and quality of life. The principles of universal design seek, above all, to support the process of designing objects and environments, so they are inclusive, without drastic adaptations for use in different population groups (Rovira, 2003). Both the universal design principles and the standards of usability and accessibility proposed by the $\mathrm{W} 3 \mathrm{C}$, seek to support design processes in order to broaden their scope.

\section{The basic heuristics of Nielsen}

Nielsen (1995) established ten basic guidelines for usability of a website to be well designed.

- Visibility of system status: system should always keep users informed of the different processes that they are executing during a certain time and in a reasonable way.

- Match between system and the real world: system should speak in the language of the user, not in the language of the system, using phrases, images and concepts that follow the conventions of the real world.

- User control and freedom: users will want to correct actions not expected by the system that they have generated, so the system must give a clearly marked emergency exit.

- Consistency and standards: the site must handle established conventions that facilitate the understanding of the contents to the users.

- Error prevention: as far as possible, any errors in the system must be prevented and any improper action by the user must be anticipated.

- Recognition rather than recall: options to carry out a process in the system should be at hand, the user should not remember processes or information.

- Aesthetic and minimalist design: dialogues should not contain information which is irrelevant or rarely used, as it would conflict with the relevant information.

- Help users: errors should be solved through a correct instruction that accurately reports to the user.

- Help and documentation: Although the site does not need to use extra documentation for its use, it is necessary to include textual assistance and additional documentation for non-experienced users requiring assistance. 
The heuristics of Nielsen (1995) have been a world reference in the design and diagnosis of errors in user interfaces, since they establish the bases for their development. They are guidelines that streamline the identification of errors in each execution area in all types of interfaces, but do not take into account the type of user that uses the interface (Becker, 2004), which clearly establishes a need for the guidelines to include persons with disabilities. Pérez (2008) used them to perform a manual evaluation of three websites targeting the elderly people and TAW CTIC (2011) for the automatic evaluation of the interfaces of each site.

\section{Recommendations of Shneiderman and Plaisant}

There are eight recommendations for the design of human-computer interaction. These recommendations are very useful when designing interfaces that are based on the specific requirements of the users (Shneiderman \& Plaisant, 2005).

- Consistency: icons, colors, fonts and other design elements that are familiar to the user should be used, so as not to force them to learn new ones and so they can use some of their cognitive heritage already apprehended.

- Shortcuts: shortcuts should be used to perform certain tasks on the system.

- Informative feedback: user should know the status of the processes running the system, what is happening.

- Dialog: system should be communicating with the user, a "thank you" for a specific action that the user executes is an information message that will keep the communication open with the user.

- Error handling: users should be given simple ways to correct errors, step by step and effectively, as this will avoid frustration.

- Permit easy reversal: the user of the interface should be allowed to step back on the steps followed in a given task, which facilitates task completion and retention of information, as well as it frees the user from anxiety.

- Encourage the sense of control: the user should be given the expected management of the system and facilitate the interaction.

- Reduction of memory load: the design of the page should be as simple as possible and demonstrate a hierarchy of information, in a way that facilitates the retention of information by the user, and thus the speed and effectiveness of each task. The user should not have to memorize very long processes or extensive information.
- Atajos: se deben usar accesos directos a la ejecución de ciertas tareas en el sistema.

- Retroalimentación informativa: el usuario debe saber cual es el estado de los procesos que esta ejecutando el sistema, qué està pasando.

- Dialogo: el sistema se debe estar comunicando con el usuario, un "gracias" por una acción determinada que el usuario ejecute es un mensaje de información que mantendrá la comunicación abierta con el usuario.

- Manejo de errores: se deben dar a los usuarios maneras sencillas de corregir los errores, paso a paso y de manera efectiva, pues ello evitará su frustración.

- Permitir la facilidad de retroceso: se debe permitir que el usuario de la interfaz retroceda sobre los pasos seguidos en determinada tarea, lo que facilita la realización de las tareas y la retencion de información, a la vez que libera de ansiedad al usuario.

- Fomentar la sensación de control: se le debe dar al usuario el manejo esperado del sistema y facilitaro la interacción.

- Reducción de la carga de memoria: el diseño de la página debe ser lo más sencillo posible y evidenciar una jerarquía de información, de manera que facilite la retención de información por parte del usuario, y así la rapidez y efectividad de cada tarea. El usuario no debe tener que memorizar procesos muy largos, ni información extensa.

Lineamientos para el programa de Gobierno en Línea (Carvajal y Saab, 2010)

Propuestos por el MinTIC de Colombia para establecer los criterios de diseño de usabilidad y accesibilidad para interfaces de usuario y a todo contenido o información que ellas contengan, tales como tipografía, contrastes, semántica del código HTML y arquitectura de la información. Son una serie de lineamientos específicos que tienen en cuenta los aspectos técnicos de la creación de sitios web, como estructura HTML y CSS, entre otros, y buscan mejorar el diseño de los sitios. Nacen de la norma técnica Icontec $5854 / 2011$ que establece todos los aspectos técnicos para la creación de portales web gubernamentales. Estos lineamientos están basados en los estándares de la WCAG 2.0 y funcionan dentro de las mismas categorías establecidas por éstas para la calificación de los portales web.

Dentro de las propuestas del MinTIC para la mejora de la accesibilidad web, se encuentra ConverTIC (ConverTIC, s.f.), la cual busca, através de dos herramientas automáticas, JAWS y MAGIC, descritas a continuación, ampliar los tipos de usuarios en situación de discapacidad, para que pueden acceder a diferentes contenidos.

- JAWS es un lector de pantalla automático que convierte a voz el contenido visible en pantalla y permite a los usuarios en situación de discapacidad acceder a contenidos de diferente tipo, ya sean aplicaciones, 
texto, imágenes o video. Trabaja de manera local en el equipo del usuario y le permite ejecutar tareas mediante comandos por voz en el sistema operativo Windows (Serrano, 2009).

- MAGIC es un software amplificador de tipografía que permite la variación de contrastes y colores en la pantalla, con el fin de hacerlos más perceptibles.

Asimismo, el MinTIC (2016) ha lanzado un sello de validación de accesibilidad que garantiza el cumplimiento de los items que ofrecen accesibilidad web en los portales.

C. Heurísticas para la evaluación de usabilidad y accesibilidad web para personas de la tercera edad

Jiménez et al., (2009) establecen que las heurísticas y métodos de evaluación de la usabilidad y la accesibilidad generales dejan de lado los aspectos propios que conllevan los usuarios en sitación de discapacidad, tales como la diminución de las capacidades visual, motriz y cognitiva. A continación se describen algunos estudios que sí han tenido en cuenta éstas discapacidades y han establecido lineamientos en las diferentes áreas que afectan a las personas de la tercera edad.

\section{Lineamientos del National Institute on Aging [NIA]}

Es una heurística propuesta por el NIA (2002) de Estados Unidos con sugerencias para el diseño de los diferentes elementos que componen un sitio web que involucre usuarios de tercera edad, tales como: tipografías, puntaje tipográfico, contrastes y combinaciones cromáticas y aspectos semánticos, como el fraseo, la navegación, la escritura y la compresión de los contenidos. Esta lista de chequeo busca establecer lineamientos para el diseño de sitios web para personas de la tercera edad.

\section{Lineamientos de Holt (2000)}

Estos lineamientos son sugerencias que abarcan cuatro grandes categorías de discapacidad: visual, intelectual, auditiva y motríz. Es uno de los primeros lineamientos existentes para el diseño de usabilidad y accesibilidad para personas de la tercera edad, sin embargo, según Arch (2008), aunque las bases de estos lineamientos no son claras, gran parte de la discución de Holt refleja los puntos de control de la iniciativa WCAG1.0.

\section{Lineamientos de la AgeLight (2001)}

Se enfocan en seis aspectos básicos: diseño y estilo, color, texto, usabilidad y pruebas generales, accesibilidad y discapacidad, y personalización del usuario. Esta lista fue elaborada con ayuda de grupos focales que ayudaron a entender el comportamiento de usuarios con discapacidades dentro de la interfaz de usuario. Muchos de los aspectos de estos lineamientos fueron captados en los estándares de la WCAG 1.0 (Arch, 2008).

\section{Lineamientos de Conie y Nielsen (2002)}

Son el primer grupo de recomendaciones para el diseño de lineamientos de usabilidad aceptadas a nivel mundial, se centran en seis áreas básicas de intervención: presen-
Guidelines for the Gobierno en Linea Program (Carvajal and Saab, 2010)

Proposed by the MinTIC of Colombia to establish the usability and accessibility design criteria for user interfaces and any content or information they contain, such as typography, contrasts, HTML code semantics and information architecture. They are a series of specific guidelines that take into account the technical aspects of website creation, such as HTML and CSS structure, among others, and seek to improve the design of sites. They are born from the technical standard Icontec 5854/2011 that establishes all the technical aspects for the creation of governmental web portals. These guidelines are based on the standards of WCAG 2.0 and work within the same categories established by them for the rating of web portals.

Among the proposals of the MinTIC for the improvement of web accessibility, it is ConverTIC (ConverTIC, s.f.), which seeks to expand, through two automatic tools JAWS and MAGIC, described below, the types of users in situations of disability, so they can access different content.

- JAWS is an automatic screen reader that turns into voice the content visible on the screen and allows disabled users to access content of different types, whether applications, text, images or video. It works locally on the computer of the user and allows to execute tasks using voice commands in the Windows operating system (Serrano, 2009).

- MAGIC is a typography amplifier software that allows the variation of contrasts and colors on the screen, in order to make them more noticeable.

Likewise, the MinTIC (2016) has launched an accessibility validation seal that guarantees the compliance of the items that offer web accessibility in the portals.

C. Heuristics for the evaluation of web usability and accessibility for the elderly people

Jiménez et al., (2009) establish that the heuristics and methods of evaluation of general usability and accessibility leave aside the own aspects that entail the users in terms of disability, such as the diminution of the visual, motor and cognitive capacities. We continue to describe some studies that have taken these disabilities into account and have established guidelines in the different areas that affect the elderly.

The following describes some studies that have taken into account these disabilities and have established guidelines in the different areas that affect the elderly people. 


\section{National Institute on Aging guideline [NIA]}

It is a heuristic proposed by the NIA (2002) of the United States with suggestions for the design of the different elements that compose a website that involves senior citizens, such as typographies, typographic score, contrasts and color combinations and semantic aspects, such as phrasing, navigation, writing and content compression. This checklist seeks to establish guidelines for the design of websites for the elderly people.

\section{Holt guidelines (2000)}

These guidelines are suggestions that cover four broad categories of disability: visual, intellectual, auditory and motor. It is one of the first existing guidelines for usability and accessibility design for the elderly people, however, according to Arch (2008), although the bases of these guidelines are not clear, big part of Holt discussion reflects the control points of the WCAG 1.0 initiative.

\section{AgeLight guidelines (2001)}

They focus on six basic aspects: design and style, color, text, general usability and testing, accessibility and disability, and user customization. This list was developed with the help of focus groups that helped to understand the behavior of users with disabilities within the user interface. Many aspects of these guidelines were captured in the WCAG 1.0 standards (Arch, 2008).

\section{Conie and Nielsen guidelines (2002)}

They are the first group of recommendations for the design of usability guidelines accepted worldwide, they focus on six basic areas of intervention: presentation of information and text; presentation of navigational elements and links; look for forms and results; presentation of articles for sale, forms and data entry; Web address; and home page. Like many other guidelines, they make general recommendations that help other groups of people aside from the elderly.

\section{ARPP guidelines (Chisnell \& Redish, 2005)}

In this study, an expert review of fifty sites belonging to different categories of services is performed and follow up on the tasks executed in the system by two contracted users. The authors propose customized guidelines to evaluate the sites, since they maintain that the aspects of the standards for usability and accessibility analysis are very general and, therefore, the customization for an efficient and correct evaluation is appropriate. tación de información y texto; presentación de elementos y enlaces de navegación; buscar formularios y resultados; presentación de artículos para la venta, formularios y entrada de datos; dirección web; y página principal. Al igual que muchos otros lineamientos, hacen recomendaciones generales que ayudan a otros grupos de personas fuera de las de la tercera edad.

\section{Lineamientos ARPP (Chisnell \& Redish, 2005)}

En este estudio se hace una revisión experta de cincuenta sitios que pertenecen a diferentes categorías de servicios y acuden al seguimiento de las tareas ejecutadas en el sistema por parte de dos usuarios contratados. Los autores proponen unos lineamientos personalizados para evaluar los sitios, ya que sostienen que los aspectos de los estándares para análisis de usabilidad y accesibilidad son muy generales y que, por lo tanto, es pertinente la personalización para una evaluación eficiente y acertada.

\section{Lineamientos de la SPRAY Foundation (1999)}

Pretenden ser una guía para el diseño y desarrollo de sitios web para personas de la tercera edad, establecen que esta población, al igual que todas las demás personas, es atraída por aspectos de conectividad, dinamismo e interactividad de las páginas, y todas las demás prestaciones que las TIC tienen como medio de comunicación y avance tecnológico. Al igual que otros lineamientos, se centran en aspectos visuales, como: colores, contrasetes, matices y fuentes tipográficas.

Lineamientos de Zaphiris, Kurniawan y Ghiwadwala (2007)

Los autores revisan la literatura sobre interacción humano-computador [HCI, Human Computer Interaction] y proponen 52 lineamientos que se derivan en once categorías, denominadas Lineamientos SilverWeb, estas son: diseño de destino (enlace); gráficos; navegación; características de la ventana del navegador; diseño del contenido; campo de golf; diseño cognitivo del usuario; uso del color y del fondo; diseño de texto; buscador; y comentarios y asistencia de los usuarios

\section{Lineamientos Webcredible (Dunn, 2006)}

Estos lineamientos son el resultado de una investigación con dos grupos de usuarios: jóvenes y tercera edad, donde se halló que el segundo grupo tendía a asignarse la culpa a sí mismo al ejecutar una tarea de manera incorrecta dentro de la interfaz, entre otros aspectos propios de la edad. Estos lineamientos categorizan:

- investigar formas de indicar que una página no termina y requiere desplazamiento;

- evitar términos técnicos, si es posible;

- identificar los vínculos de una manera coherente y obvia;

- lograr que los enlaces capten la atención;

- cambiar el color en los enlaces visitados; 
- proporcionar todo el contenido como HTML, cuando sea posible;

- hacer que el contenido sea lo más claro y conciso posible;

- proporcionar un vínculo "haga que la escritura sea más grande" y usar siempre alto contraste; y

- proporcionar instrucciones explícitas, usando las formas imperativas de los verbos.

Documento para evaluar páginas web sanitarias según criterios europeos

Bermúdez et al., (2006) desarrollan un documento para la evaluación de sitios web sanitarios, según criterios europeos, que adecua los lineamientos establecidos por la WCAG a los requerimientos propios de un portal web sanitario. Contiene unos campos para llenar a mano que enfoca el análisis heurístico sobre los aspectos semánticos de los sitios web. Debido que es un documento validado para el análisis de sitios web, resulta ser un referente en habla hispana para la evaluación de sitios web sanitarios.

Becker (2004) lo usa en el análisis de 125 sitios con oferta de contenidos web sobre salud para personas de la tercera edad; Trabalón (2012), para la evaluación de 23 páginas web con información sobre hipertensión arterial; Calvo (2014), para evaluar 53 sitios web de hospitales de España que prestan servicios de salud y son puntos prioritarios de salud en su ciudad; y Jiménez et al., (2009) para el analisis de la accesibilidad de 35 sitios web españoles sobre salud. Es usado además por Conesa, Aguinana y Hernández (2011), quienes evaluan la calidad de algunas páginas web de salud en España, realizan un análisis estadístico y concluyen un bajo nivel de calidad en la información; y por Fernández (2016), quien realiza un estudio sobre la calidad de sitios web relacionada con información sanitaria de obsetricia y maternidad, aplicando el cuestionario y analizando qué tipo de información planteaban.

Estos lineamientos obedecen a necesidades muy propias de la población de la tercera edad que presentan discapacidades que requieren ser abarcadas en el diseño de usabilidad. Al respecto, Jiménez et al., (2009, p. 347) sugieren:

...para futuras investigaciones, además de la accesibilidad, que engloba requisitos técnicos y las condiciones físicas y cognitivas propias de la vejez, que es necesario evaluar la adecuación de los sitios web a las necesidades y expectativas de las personas mayores, además de la calidad de la información proporcionada.

Las múltiples discapacidades asociadas a la tercera edad ponen de manifiesto la necesidad de lineamientos específicos que dirijan el diseño de la usabilidad a cada tipo de discapacidad, es imprescindible que el diseño de usabilidad comprenda muy bien los estándares requeridos por cada área y los aplique. En las Tablas 2, 3 y 4 se presentan las principales recomendaciones relacionadas con los lineamientos listados.

\section{SPRAY Foundation guidelines (1999)}

They pretend to be a guide for the design and development of websites for the elderly people, they state that this population, like all other people, is attracted by aspects of connectivity, dynamism and interactivity of the pages, and all other benefits that ICT have as a means of communication and technological advancement. Like other guidelines, they focus on visual aspects, such as colors, contrasts, nuances and typographic fonts.

\section{Zaphiris, Kurniawan and Ghiawadwala guidelines (2007)}

The authors review the literature about Human Computer Interaction [HCI] and propose 52 guidelines that are derived in eleven categories, called SilverWeb Guidelines, these are: design of destination (link); graphics; navigation; browser window features; content design; golf course; cognitive user design; use of color and background; text design; search engine; and comments and user support.

\section{Webcredible guidelines (Dunn, 2006)}

These guidelines are the result of an investigation with two groups of users: young and old people, where it was found that the second group tended to assign the blame to itself when executing a task in an incorrect way within the interface, among other aspects proper of the age. These guidelines categorize:

- investigate ways to indicate that a page does not end and requires movement;

- avoid technical terms, if possible;

- identify links in a coherent and obvious way;

- assure that links attract attention;

- change the color in visited links;

- provide all content as HTML, where possible;

- make the content as clear and concise as possible;

- provide a link "make the writing bigger" and always use high contrast; and

- provide explicit instructions, using the imperative forms of verbs.

\section{Document to evaluate health web pages according to European criteria}

Bermúdez et al., (2006) develope a document for the evaluation of health web sites, according to European criteria, which adapt the guidelines established by the WCAG to the requirements of a health web portal. It contains hand-filled fields that focus the heuristic analysis on the semantic aspects of web sites. Due to it is a validated document for the analysis of websites, it turns out to be a guide in Spanish-speaking for the evaluation of health web sites. 


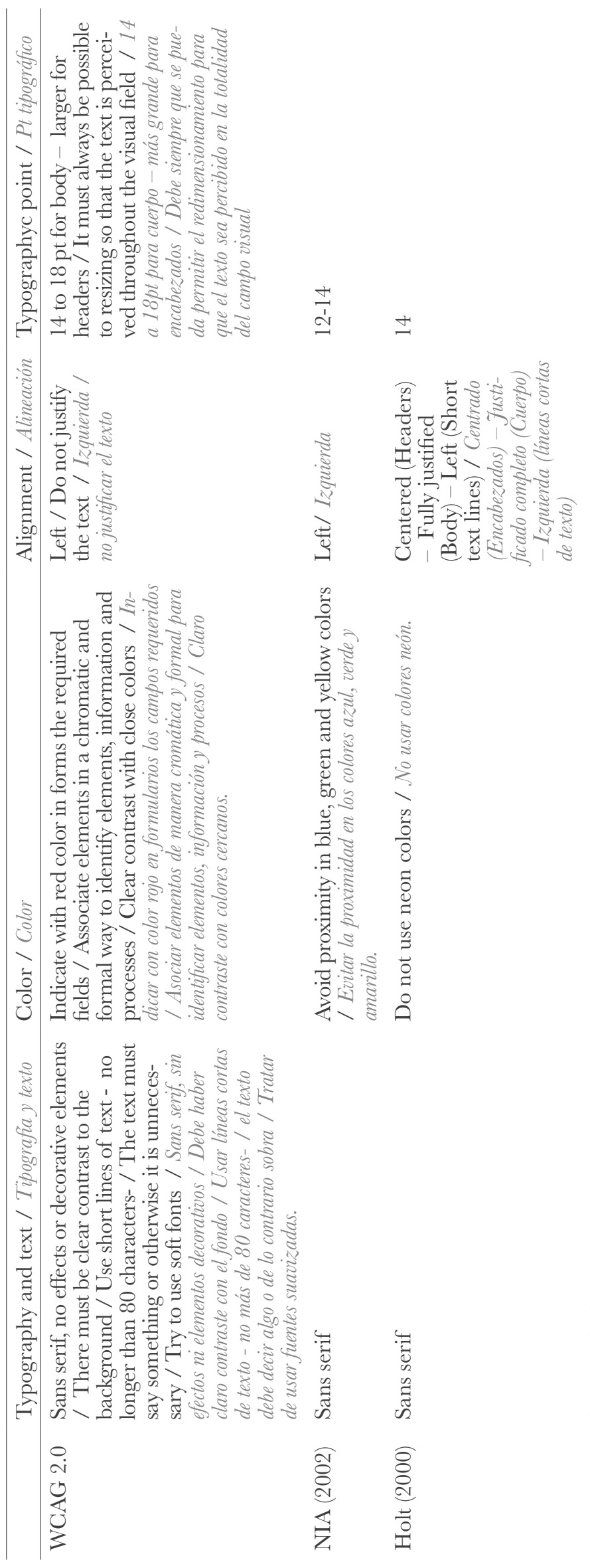

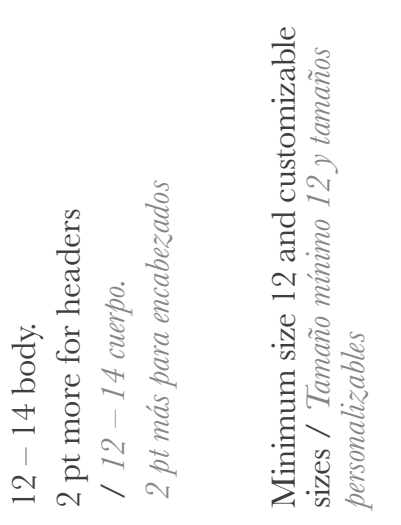
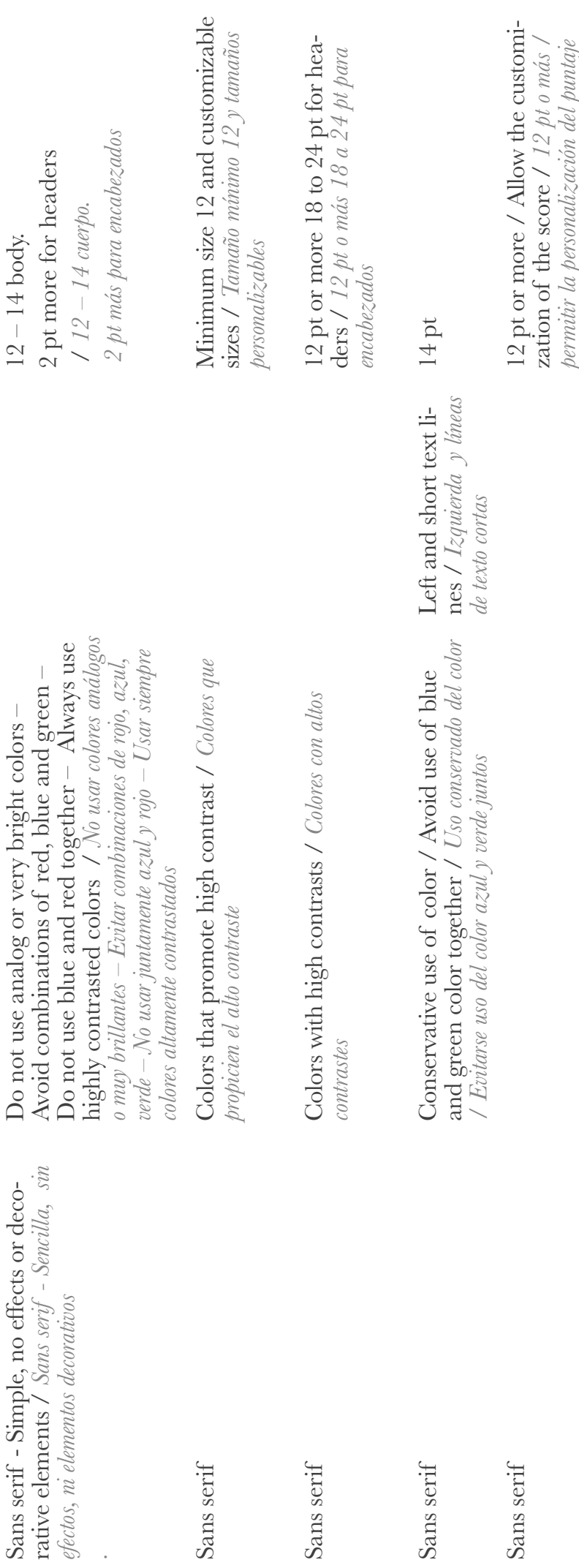

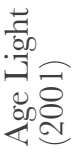
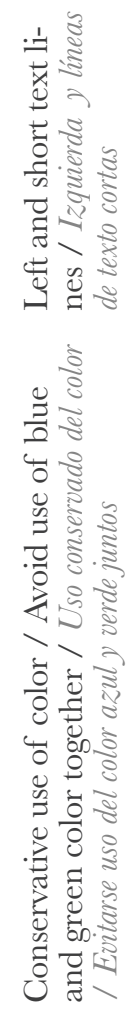

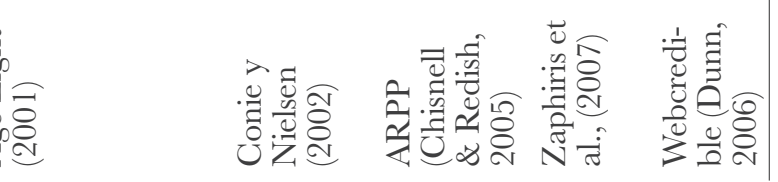




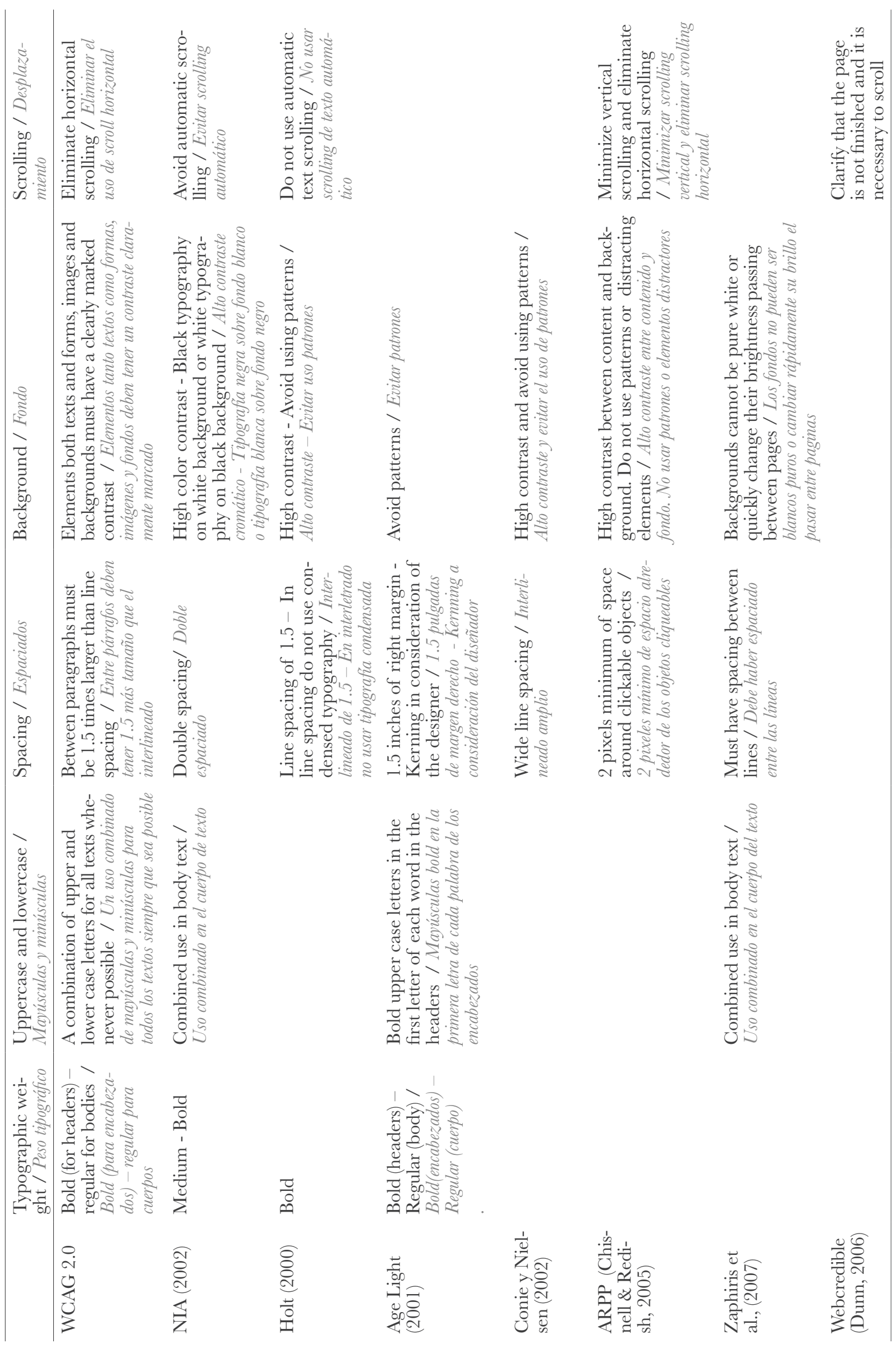




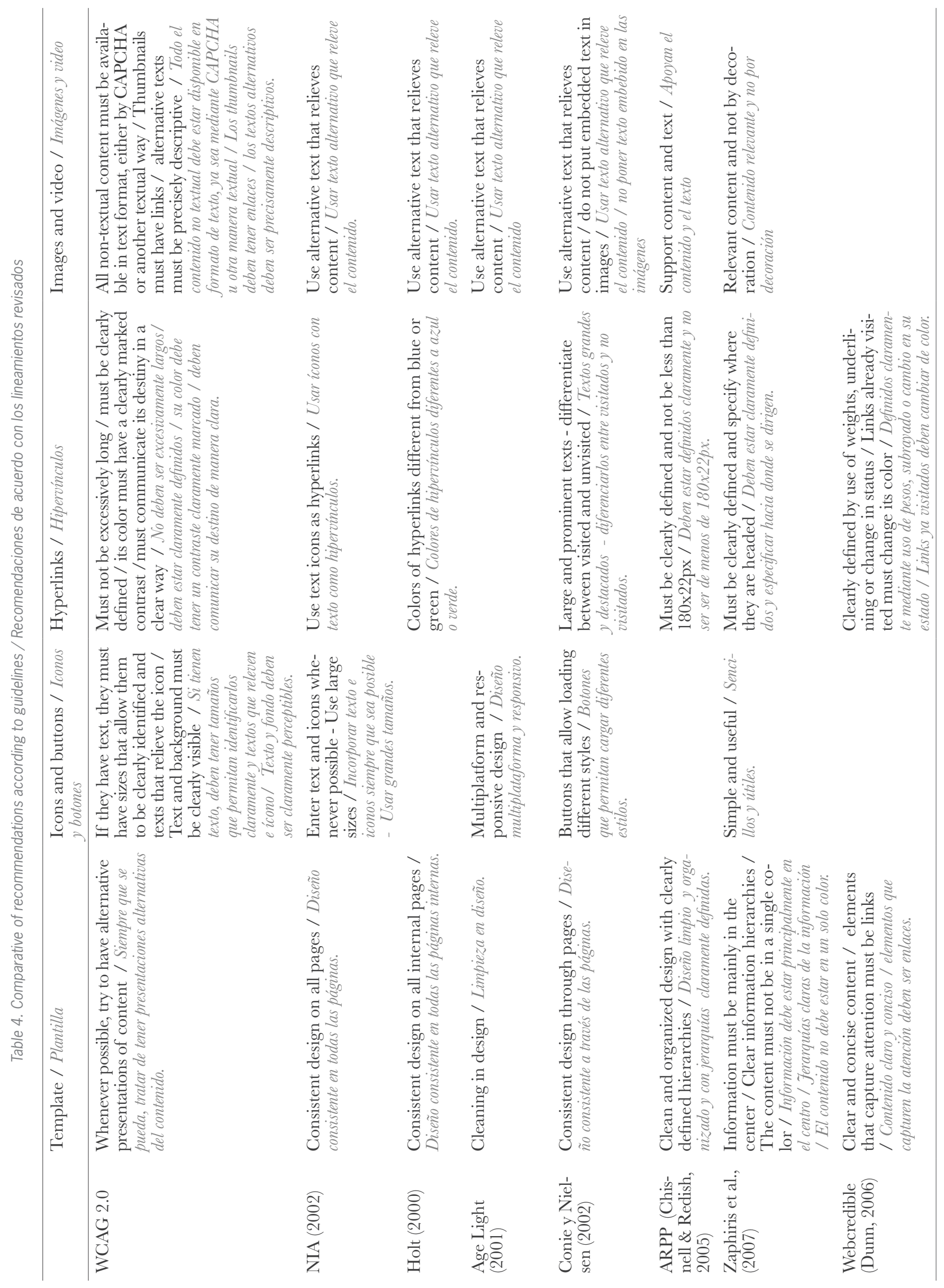




\section{Discusión y conclusiones}

Las personas de la tercera edad son inmigrantes digitales, es decir, no pertenecen a la generación de la tecnología, fueron educados de manera distinta y por tanto aprenden, sobre estas materias, de manera más lenta que los 'nativos digitales, quienes nacieron en la época tecnológica y están acostumbrados a enlaces directos a información extra y ven más de 20.000 horas de televisión al año, entre otros excesos de información (Prensky, 2001). De esto se desprenden las múltiples dificultades que una persona de la tercera edad puede tener al momento de enfrentearse a las interfaces digitales y a los conocimientos e información recibida por estos medios, sin contar con las dificultades motrices propias de su edad.

Es importante entonces el 'buen diseño' en las interfaces digitales, lo que según Galitz (2007) puede llegar a aumentar la productividad de los usuarios de un $25 \%$ a un $40 \%$ e impactar en los aspectos económicos de las empresas. Entre muchos otros aspectos, menciona el autor, es necesario conocer las necesidades de los usuarios y entender los objetivos de las interfaces para que las tareas de los usuarios no resulten frustrantes $y / o$ fatigosas.

Los sitios web son productos que deben explicarse a sí mismos ante el usuario, independientemente del tipo de sitio que sea; deben poder facilitar la ejecución de tareas dentro de sí mismos y no volver frustrante el proceso $(\mathrm{Ga}-$ rret, 2011). Por ello, es necesario investigar las necesidades de los usuarios y diseñar interfaces a su medida, que puedan ser útiles para los objetivos que se quieren crear (Chisnell \& Redish, 2005).

Una parte importante del proceso son las herramientas de validación de usabilidad nombradas, las cuales permiten conocer los problemas que las páginas plantean y que pueden ser mejorados para favorecer una mejor interacción con sus usuarios, en especial cuando de temas de accesibilidad se trata.

Involucrar la tecnología en las necesidades de las personas de la tercera edad tiene beneficios que aún no se aprovechan al máximo, que van desde mejorar las relaciones con los pacientes de determinadas enfermedades y la comunicación de peticiones por parte de las personas de la tercera edad, hasta mejorar la calidad de los contenidos web sobre salud que un paciente puede llegar a consultar (Bodenheimer \& Grumbach, 2003).

Todos los aspectos y recomendaciones de accesibilidad no deben ser considerados únicamente para las personas en situación de discapacidad sensorial, sino también para usuarios comunes, personas con disminuciones cognitivas, para diferentes plataformas, para diferentes usos (incluso educativos) y para usuarios extranjeros (Abadía, 2012). Estas tecnologías están enfocadas en resolver problemas comunicativos en los diferentes grupos de población, por lo que su uso no debería limitarse.

En general, no existe un acuerdo que plantee a nivel internacional recomendaciones claras para el diseño de contenido digital para población de la tercera edad. Asimis-
Becker (2004) uses it in the analysis of 125 sites offering web content on health for the elderly people; Trabalón (2012), for the evaluation of 23 web pages with information on arterial hypertension; Calvo (2014), to evaluate 53 websites of hospitals in Spain that provide health services and are priority health points in his city; and Jiménez et al., (2009) for the analysis of the accessibility of 35 Spanish health websites. It is also used by Conesa, Aguinana and Hernández (2011), who evaluate the quality of some health web pages in Spain, perform a statistical analysis and conclude a low level of quality in information; and by Fernández (2016), who carried out a study on the quality of websites related to obstetrical and maternity health information, applying the questionnaire and analyzing what kind of information they posed.

These guidelines arise from very specific needs of the elderly population with disabilities that need to be covered in the usability design. In that regard, Jiménez et al., (2009, p. 347) suggest:

...for future research, in addition to accessibility, which encompasses technical requirements and the physical and cognitive conditions of old age, it is necessary to evaluate the adequacy of websites to the needs and expectations of older people, in addition to the quality of the provided information.

The multiple disabilities associated with the elderly show the need for specific guidelines that guide usability design to each type of disability, it is imperative that the usability design understands very well the standards required by each area and apply them. TABLES 2, 3 and 4 present the main recommendations related to the listed guidelines.

\section{Discussion and conclusions}

The elderly people are digital immigrants, that is, they do not belong to the generation of technology, they were educated in a different way and therefore they learn, on these subjects, in a slower way than the digital natives, who were born in the technological age and are accustomed to direct links to extra information and watch more than 20.000 hours of television a year, among other excesses of information (Prensky, 2001). This results in the multiple difficulties that a person of the elderly can have at the moment of facing the digital interfaces and the knowledge and information received by these means, without taking into account the motor difficulties specific to this age.

It is important then the 'good design' in the digital interfaces, which according to Galitz (2007) can increase the productivity of users from $25 \%$ to $40 \%$ and impact on the eco- 
nomic aspects of companies. Among many other aspects, the author mentions it is necessary to know the needs of the users and to understand the objectives of the interfaces, so that the tasks of the users are not frustrating or tiring.

Websites are products that must explain themselves to the user, regardless of the type of site; should be able to facilitate the execution of tasks within themselves and not make the process frustrating (Garrett, 2011). Therefore, it is necessary to investigate the needs of the users and to design interfaces to their measure, that can be useful for the objectives that are wanted to create (Chisnell \& Redish, 2005).

An important part of the process are the usability validation tools named, which allow to know the problems that the pages pose and that can be improved to favor a better interaction with its users, especially when it comes to accessibility issues.

Involving technology in the needs of the elderly people has benefits that are not yet fully exploited, ranging from improving relationships with patients to certain diseases and communicating requests by the elderly people, to improve the quality of health web content that a patient can consult (Bodenheimer \& Grumbach, 2003).

All accessibility aspects and recommendations should not be considered only for people with sensory disabilities, but also for common users, people with cognitive impairments, for different platforms, for different uses (including education) and for foreign users (Abadía, 2012). These technologies are focused on solving communicative problems in different population groups, so their use should not be limited.

In general, there is no agreement at the international level that considers clear recommendations for the design of digital content for the elderly population. Likewise, in Colombia there are no specific guidelines for accessibility and usability for this population, although some laws and decrees emphasize the importance of considering them within the processes of digital creation. A contribution of the present work is to leave the doors open, for the proposal of guidelines according to the technological, contextual and social conditions of the country, that favor the access and consumption of digital contents by the elderly people.

\section{Acknowdledges}

This article is part of the degree project titled "Construction of accessibility and usability guidelines for the design of health content web sites for the elderly people in the city of Cali" by student Diego Aguirre of the Graphic Design program of the University of Valle. SST mo, en Colombia no existen lineamientos específicos de accesibilidad y de usabilidad para esta población, aunque algunas leyes y decretos destaquen la importancia de considerarlos dentro de los procesos de creación digital. Un aporte del presente trabajo es entonces, dejar las puertas abiertas, para la proposición de lineamientos acordes con las condiciones tecnológicas, contextuales y sociales del país, que favorezcan el acceso y el consumo de contenidos digitales en públicos de la tercera edad.

\section{Reconocimiento}

El presente artículo forma parte del proyecto de grado titulado "Construcción de lineamientos de accesibilidad y usabilidad para diseño de sitios web de contenidos sobre salud para personas de la tercera edad de la ciudad de Cali" del estudiante Diego Aguirre del Programa de Diseño Gráfico de la Universidad del Valle. ST 


\section{References / Referencias}

Abadía, I. (2012). Revisión de lineamientos para el desarrollo de contenido educativo para televisión digital interactiva. Sistemas \& Telemática, 10(20), 71-104.

Achecker (2011). Web Accessibility Checker. Retrieved from: https://achecker.ca/checker/index.php

Age Light. (2001). AgeLight LCC. . Retrieved from: http://www.agelight.com/webdocs/designguide.pdf

Aldana, G., García, L. \& Jacobo, A. (2012). Las tecnologías de la información y comunicación como alternativa para la estimulación de los procesos cognitivos en la vejez. CPU-e, Revista de Investigación Educativa, 14, 153-166.

Allés, M.T. (2012). Los consumidores de la tercera edad y el diseño universal. Boletín Económico de Ice, 3026, 46-56.

Aparicio, L. \& Castang, G. (2006). Análisis del estado de la medicina en linea en Colombia y propuesta para diseño de portales de salud. Vínculos, 2(2), 4-18.

Arch, A. (2008). Web accessibility for older users: A literature review. Retrieved from: https://www.w3.org/TR/wai-age-literature/

Becker, S.A. (2004). A study of web usability for older adults seeking online health resources. ACM Transactions on Computer-Human Interaction, 11(4), 387-406.

Berland et al. (2001). Health information on the Internet: Accessibility, quality, and readability in english and spanish. JAMA, 285(20), 2612-2621.

Bermudez, C., Jimenez, J., García, J., Azpilicueta, I., Silva, M., Babio, G., \& Plazaola, J. (2011). Cuestionario para evaluar paginas web sanitarias según criterios europeos. Retrieved from: http://www.elsevier.es/es-revista-atencion-primaria-27-articulo-cuestionario-evaluar-sitios-web-sanitarios-13092985

Bodenheimer, T., \& Grumbach, K. (9 de Julio de 2003). Electronic Technology: a spark to revitalize primary care? JAMA, 290(2), 259-264. doi:doi:10.1001/jama.290.2.259

Calvo, M. (2014). Calidad y características de los sitios web de los hospitales españoles de gran tamaño. Revista Española de Documentación Científica, 37(1). http://dx.doi.org/10.3989/redc.2014.1.1049

Carvajal, M. \& Saab, J. (2010). Lineamientos y metodologías en usabilidad para el gobierno en línea. MinTIC, Colombia. Retrieved from: http://estrategia.gobiernoenlinea.gov.co/623/articles-8237_guia_usabilidad.pdf

Chisnell, D., \& Redish, J. (2005). Designing web sites for older adults: Expert review of usability for older adults at 50 web sites. Retrieved from: https://assets.aarp.org/www.aarp.org_/articles/research/oww/AARP-50Sites.pdf

Conesa, M., Aguinana, E. \& Hernández, J. (2011). Evaluación de la calidad de las páginas web sanitarias mediante cuestionario validado. Atención Primaria, 43(1), 33-40.

Conie, K. \& Nielsen, J. (2002). Web Usability for Senior Citizens - design guidelines based on usability studies with people age 65 and older. Nielsen Norman Group. Retrieved from: https://www.nngroup.com/articles/usability-for-senior-citizens/

Connel, B. et al. (1997). The principles of universal design. Retrieved from: https://www.ncsu.edu/ncsu/design/cud/about_ud/ udprinciplestext.htm

ConverTIC. (s.f.). ConverTIC. Retrieved from: http://www.convertic.gov.co/641/w3-propertyvalue-15308.html

de Oleo, C. \& Rodríguez, L. (2013). Pautas, métodos y herramientas de evaluación de accesibilidad web. Ventana Informática, 28, 99-115.

Decreto 2693 de 2012 [MinTIC]. (2012, diciembre 21). Diario Oficial de la República de Colombia No. 48651.

Dunn, T. (2006, Feb.). Usability for older web users. Retrieved from: https://www.webcredible.co.uk/user-friendly-resources/ web-usability/older-users.shtml

Edu Labs S.A.S. (2015). Validación de Accesibilidad Web NTC 5854. Retrieved from: http://ntc5854.org/validador/checker/ index.php

Examinator (2015). Evaluación de la accesibilidad web. Retrieved from: http://examinator.ws/

Fenoll, V. (2011). Usuarios activos y pasivos, la interactividad de la audiencia en los medios digitales: el caso de la fórmula 1 en Valencia. Aposta, 51, 1-26.

Fernández, M. (2016). Evaluación de calidad de páginas web sobre obstetricia y ginecología para las gestantes de atención primaria. Matronas profesión, 17(4), 149-156.

Galitz, O. W. (2007). The esential guide to user interface design. New York, NY: Wiley.

Garret, J. (2011). The elements of user experience. Berkeley, CA: New Riders.

Holt, B. (2000). Creating senior-friendly web sites. Issue Brieff, 1(4). Retrieved from: http://catalogue.iugm.qc.ca/GEIDEFile/21914.PDF?Archive $=101562492974 \&$ File $=21914$ PDF

Icontec. (2011). NTC 5854: accesibilidad a páginas web. Retrieved from: http://www.meta.gov.co/web/sites/default/files/adjuntos/NTC5854.pdf

Jiménez, J., García, J. \& Bermudez, C. (2009). Accesibilidad de sitios web sobre salud para mayores. Revista Española de Geriatría y Gerontología, 44(6), 342-348.

Jiménez, J., García, J., Martín, J. \& Bermudez, C. (2007). Tendencias en el uso de internet como fuente de información sobre salud. UOC Papers, 4, 44-50.

Ley 1680 de 2013. (2013, noviembre 20). Diario Oficial de la República de Colombia No. 48980.

Ministerio de Salud y Protección Social. (2014, april 4). Estudio exploratorio de la situación de la telemedicina en municipios priorizados - Colombia: resultados generales. Retrieved from: https://www.minsalud.gov.co/sites/rid/Lists/BibliotecaDigital/ RIDE/VS/PSA/estudio-exploratorio-telemedicina-municipios-priorizados-colombia.pdf 
Ministerio de Salud y Protección Social. (2015). Sabe Colombia2015: estudio nacional de salud, bienestar y envejecimiento. Retrieved from: https://www.minsalud.gov.co/sites/rid/Lists/BibliotecaDigital/RIDE/VS/ED/GCFI/Resumen-Ejecutivo-Encuesta-SABE.pdf

Ministerio de Salud y Protección Social. (2016). Estudio exploratorio de la situación de la telemedicina en municipios priorizados - Colombia. Resultados Generales. Retrieved from: https://www.minsalud.gov.co/sites/rid/Lists/BibliotecaDigital/RIDE/ VS/PSA/estudio-exploratorio-telemedicina-municipios-priorizados-colombia.pdf

Ministerio de Tecnologías de la Información y las Comunicaciones [MinTIC]. (2016). MinTIC presenta Sello de Accesibilidad Web. Retrieved from: http://www.mintic.gov.co/portal/604/w3-article-30015.html

National Institute of Aging [NIA] (2002). Making your website senior friendly: Checklist. Retrieved from: https://www.nlm.nih. gov/pubs/checklist.pdf

Nielsen, J. (1995, Jan. 1). 10 usability heuristics for user interface design. Retrieved from: https://www.nngroup.com/articles/ ten-usability-heuristics

Pérez, A. (2008). Usabilidad de sitios web para personas de la tercera edad. Retrieved from: http://openaccess.uoc.edu/ webapps/02/bitstream/10609/457/1/00914tfc.pdf

Petrié, H. \& Edwards, A. (2006). Inclusive design and assistive technology as part of the HCl curriculum. Retrieved from: https://www.researchgate.net/publication/228348765_Inclusive_design_and_assistive_technology_as_part_of_the_HCl_ curriculum

Prensky, M. (2001). Digital natives, digital immigrants. Retrieved from: https://www.marcprensky.com/writing/Prensky\%20 -\%20Digital\%20Natives,\%20Digital\%20Immigrants\%20-\%20Part1.pdf

Rafe, V. \& Monfaredzadeh, M. (2012). A qualitative framework to assess hospital/medical websites. Journal of Medical Systems, 36(5), 2927-2939. doi: 10.1007/s10916-011-9771-5

Rovira, E. (2003). El libro blanco de la accesibilidad. Madrid, España: Ministerio de Trabajo y Asuntos Sociales.

Serrano, E. (2009). Herramientas para la evaluación de la accesibilidad web. Documentación de las Ciencias de la Información, 32, 245-266

Snneiderman, B. \& Plaisant, C. (2005). Diseño de interfaces de usuario. México: Pearson.

SPRAY Foundation. (1999). Spray foundation. Retrieved from: http://www.spry.org/pdf/website_creators_guide.pdf

TAW CTIC. (2011). Analizador WCAG 2.0. Retrieved from: http://www.tawdis.net/

Trabalón, I. (2012). Analisis de calidad de páginas web sobre hipertensión arterial de habla hispana. Revista Española de Comunicación en Salud AECS, 3(1), 3-15.

Varela, C. et al. (2012). Estándares y legislación sobre accesibilidad web. Actas del IV Congreso Internacional ATICA, (pp. 46-56). Loja, Ecuador.

W3C. (2008). Web Content Accessibility Guidelines (WCAG) 2.0. Retrieved from: http://www.w3.org/TR/WCAG20/

Zaphiris, P., Kurniawan, S. \& Ghiawadwala, M. (2007). A Systematic Approach to the Development of Research-Based Web Design Guidelines for Older People. Universal Access in the Information Society Journal, 6, 59-76. 


\section{CURRICULUM VITAE}

Diego Fernando Aguirre Graphic Design student at the Universidad del Valle (Cali-Colombia). In his degree thesis he developed a set of guidelines for the design of digital content for elderly people, which favor aspects of accessibility and usability / Estudiante de diseño gráfico de la Universidad del Valle (Cali-Colombia). En su tesis de grado desarrolló lineamientos para el diseño de contenido digital para personas de la tercera edad que favorecen aspectos de accesibilidad y de usabilidad.

Iván Abadía Quintero Graphic Designer from the Universidad del Valle (Cali-Colombia) and Specialist and candidate for Master's Degree in Design Theory from the University of Buenos Aires (Argentina). Research assistant for seven years in the Computer and Telecommunications Research Group (i2t) of Universidad Icesi (Cali, Colombia). In two opportunities he was part of the Young Researchers Program (Colciencias), where he was focused in digital areas of accessibility and usability, and participated in several projects in technological and creative areas. Member of the i2t group of the University Icesi and the Aiesthesis group of the Instituto Departamental de Bellas Artes. His main area of activity is the analysis of the practices of production, communication and reproduction of digital images in social networks / Diseñador Gráfico de la Universidad del Valle (Cali-Colombia) y Especialista y candidato a Máster en Teoría del Diseño de la Universidad de Buenos Aires (Argentina). Asistente de investigación durante siete años en el Grupo de Investigación en Informática y Telecomunicaciones (i2t) de la Universidad Icesi. Joven investigador de Colciencias en dos oportunidades, en áreas digitales de accesibilidad y usabilidad, y participante de al menos una docena de proyectos en ámbitos tecnológicos y creativos. Miembro del grupo i2t de la Universidad Icesi y del grupo Aiesthesis del Instituto Departamental de Bellas Artes. Su principal área de actuación es el análisis de las prácticas de producción, comunicación y reproducción de imágenes digitales en redes sociales. 